\title{
Synthesis of Cerite
}

\author{
Jun Ito \\ Institute for Materials Research, National Bureau of Standards, Washington, D.C. 20234
}

(April 29, 1968)

\begin{abstract}
Some compounds isostructural with cerite have been synthesized hydrothermally at temperatures from 500 to $720^{\circ} \mathrm{C}$. The compositional range for cerite, and its phase relation to the silicate apatites are established in terms of ionic radii of rare-earth and divalent ions. The proposed formula for cerite on the basis of isomorphism with whitlockite, $\mathrm{Ca}_{3}\left(\mathrm{PO}_{4}\right)_{2}$, is discussed. A solid-solution series between $\mathrm{Ca}_{9} \mathrm{P}_{6} \mathrm{O}_{24}-\mathrm{Ca}_{7} \mathrm{Mg}_{2} \mathrm{P}_{6} \mathrm{O}_{24}$ (whitlockite-Mg-whitlockite) has been established.
\end{abstract}

Key Words: Ca, Mg phosphate, hydrothermal synthesis, inorganic synthesis, mineral chemistry, rare-earth silicate, $x$-ray powder analysis.

\section{Introduction}

During a study of silicate apatites, a very wide compositional range for the cerite phase was found under hydrothermal conditions [1]. ${ }^{1}$ This range adjoins that for the rare-earth silicate apatites. Despite its early description, the rare-mineral cerite [2-7], from which the element cerium was discovered, has not yet been fully characterized, because of the complexity of its composition. In this paper, therefore, I report the conditions for its formation and its compositional range. Recently Keppler [8] reported an isostructural relation between cerite and whitlockite. I suspect that the maximum number of $\mathbf{M g}$ ions in Mg-whitlockite may equal the number of divalent ions in cerite, consequently, the whitlockite-Mgwhitlockite solid-solution series was also investigated and the results are given here.

\section{Results and Discussion}

Cerite was synthesized from hydrosilicates which were precipitated in the ratio $\mathbf{M}^{2+}: \mathrm{M}^{3+}$ (i.e., rare earth): $\mathrm{M}^{4+}$ (i.e., $\mathrm{Si}$ ) $=2: 7: 6$. The precipitates were centrifuged, washed, dried, and in some experiments admixed with carbonates. The synthesis was completed by hydrothermal heating at $2 \mathrm{kbar}$ and 550 to $680{ }^{\circ} \mathrm{C}$. Whitlockite was synthesized from stoichiometric mixtures, prepared by the slow evaporation of alkaline solution containing calcium, magnesium nitrate and ammonium dihydrogen phosphate and heated in air at 1050 to $1120^{\circ} \mathrm{C}$. Experimental results are given in table 1 with the unit-cell dimensions calculated accord-

${ }^{1}$ Figures in brackets indicate the literature references at the end of this paper. ing to the space group R3c [6]. X-ray powder diffraction data of $\mathrm{Mg}-\mathrm{La}, \mathrm{Mg}-\mathrm{Ho}$, and Co-La cerites and Mg-whitlockite, $\mathrm{Mg}_{2} \mathrm{Ca}_{7} \mathrm{P}_{6} \mathrm{O}_{24}$, were indexed and are given in tables 2 and 3.

TABLE 1. Results of the synthesis of cerite, whitlockite and Mgwhitlockite and the unit cell dimensions

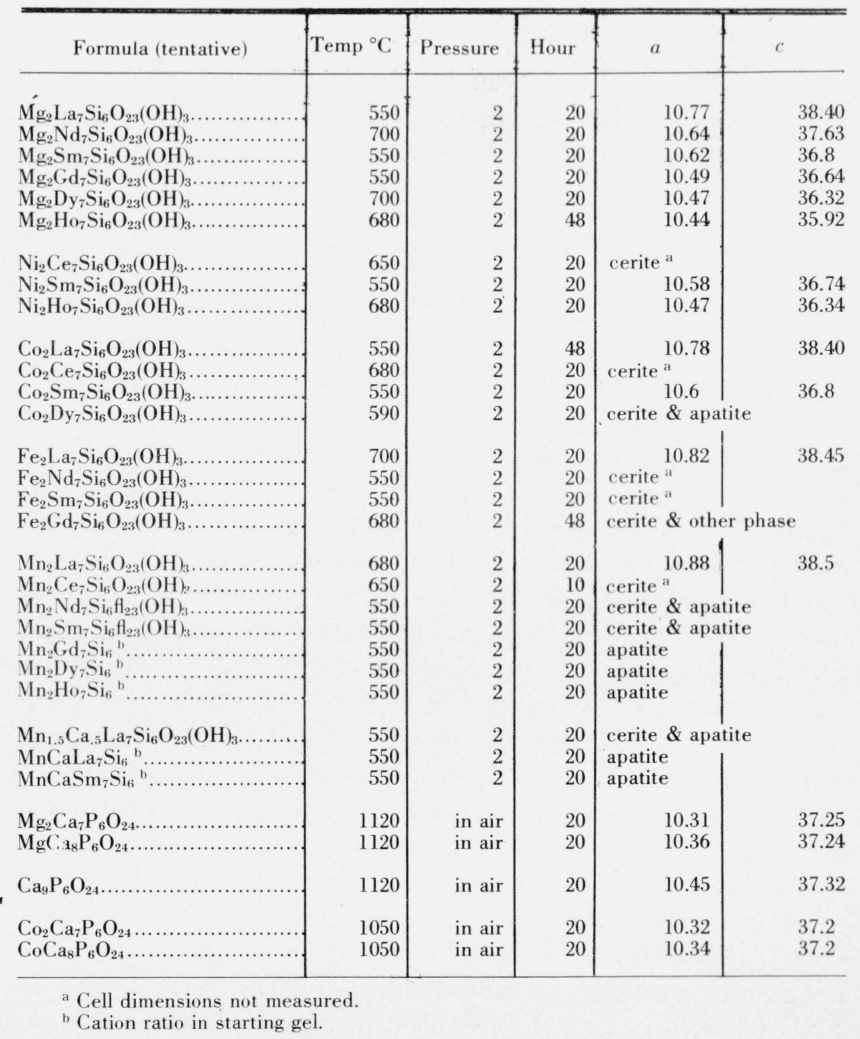


TABLE 2. X-ray powder diffraction data for synthetic cerites and magnesium whitlockite $(\mathrm{Cu} \mathrm{K} \alpha, \mathrm{Ni}$ filter $)$

Space group R3c, Hexagona!

\begin{tabular}{|c|c|c|c|c|c|c|}
\hline Formula & \multicolumn{2}{|c|}{$\mathrm{Mg}_{2} \mathrm{La}_{7} \mathrm{Si}_{6} \mathrm{O}_{23}(\mathrm{OH})_{3}$} & \multicolumn{2}{|c|}{$\mathrm{Mg}_{2} \mathrm{Ho}_{7} \mathrm{Si}_{6} \mathrm{O}_{23}(\mathrm{OH})_{3}$} & \multicolumn{2}{|c|}{$\mathrm{Co}_{2} \mathrm{La}_{7} \mathrm{Si}_{6} \mathrm{O}_{23}(\mathrm{OH})_{3}$} \\
\hline Conditions & \multicolumn{2}{|c|}{$550^{\circ} \mathrm{C} 2 \mathrm{kbar}$} & \multicolumn{2}{|c|}{$550^{\circ} \mathrm{C} 2$ kbar } & \multicolumn{2}{|c|}{$550{ }^{\circ} \mathrm{C} 2 \mathrm{kbar}$} \\
\hline $\begin{array}{l}h k l \\
012 \\
104 \\
006\end{array}$ & $\begin{array}{l}d \text { obs. } \\
8.378 \\
6.661 \\
6.421\end{array}$ & $\begin{array}{c}I / I_{0} \\
3 \\
3 \\
5\end{array}$ & $\begin{array}{r}d \text { obs. } \\
8.110 \\
6.393 \\
\ldots \ldots \ldots \ldots . . .\end{array}$ & $\begin{array}{c}I / I_{0} \\
10 \\
5\end{array}$ & $\begin{array}{r}d \text { obs. } \\
8.445 \\
\ldots \ldots \ldots \ldots . . .\end{array}$ & $\begin{array}{r}I / I_{0} \\
3\end{array}$ \\
\hline $\begin{array}{l}110 \\
202\end{array}$ & $\begin{array}{l}5.376 \\
4.532\end{array}$ & $\begin{array}{l}20 \\
25\end{array}$ & $\begin{array}{l}5.217 \\
4.379\end{array}$ & $\begin{array}{l}20 \\
30\end{array}$ & $\begin{array}{l}5.440 \\
4.535\end{array}$ & $\begin{array}{l}15 \\
30\end{array}$ \\
\hline $\begin{array}{l}018 \\
116 \\
024\end{array}$ & $\begin{array}{l}4.273 \\
4.137\end{array}$ & $\begin{array}{r}30 \\
5\end{array}$ & 4.026 & 60 & 4.275 & 20 \\
\hline $\begin{array}{r}10,10 \\
122\end{array}$ & $\begin{array}{l}3.545 \\
3.466\end{array}$ & $\begin{array}{l}25 \\
60\end{array}$ & 3.351 & 90 & $\begin{array}{l}3.561 \\
3.479\end{array}$ & $\begin{array}{l}15 \\
40\end{array}$ \\
\hline $\begin{array}{r}208 \\
214 \\
00,12\end{array}$ & $\begin{array}{l}3.348 \\
3.304 \\
3.222\end{array}$ & $\begin{array}{l}10 \\
30\end{array}$ & $\begin{array}{c}3.193 \\
\ldots \ldots \ldots \ldots\end{array}$ & $\begin{array}{c}60 \\
\ldots \ldots .\end{array}$ & $\begin{array}{l}3.353 \\
3.316\end{array}$ & $\begin{array}{l}10 \\
40\end{array}$ \\
\hline $\begin{array}{r}300 \\
02,10\end{array}$ & $\begin{array}{l}3.222 \\
3.112 \\
2.964\end{array}$ & $\begin{array}{r}5 \\
25 \\
100\end{array}$ & $\begin{array}{l}3.129 \\
3.019 \\
2.813\end{array}$ & $\begin{array}{r}5 \\
50 \\
100\end{array}$ & $\begin{array}{l}3.116 \\
2.968\end{array}$ & $\begin{array}{r}40 \\
100\end{array}$ \\
\hline $\begin{array}{r}128 \\
300 \\
220 \\
21,10 \\
312\end{array}$ & $\begin{array}{l}2.859 \\
2.801 \\
2.691 \\
2.600 \\
2.547\end{array}$ & $\begin{array}{r}20 \\
25 \\
50 \\
20 \\
3\end{array}$ & $\begin{array}{l}2.728 \\
2.693 \\
2.608 \\
2.478\end{array}$ & $\begin{array}{l}30 \\
50 \\
60 \\
30\end{array}$ & $\begin{array}{l}2.848 \\
2.801 \\
2.698 \\
2.606\end{array}$ & $\begin{array}{l}20 \\
20 \\
70 \\
15\end{array}$ \\
\hline 134 & 2.497 & 5 & 2.417 & 5 & & \\
\hline $\begin{array}{r}20,14 \\
042\end{array}$ & $\begin{array}{l}2.367 \\
2.327\end{array}$ & $\begin{array}{l}3 \\
5\end{array}$ & $\begin{array}{r}2.224 \\
\ldots \ldots \ldots \ldots\end{array}$ & 5 & 2.366 & 5 \\
\hline $\begin{array}{r}318 \\
30,12\end{array}$ & $\begin{array}{l}2.268 \\
2.231\end{array}$ & $\begin{array}{r}3 \\
20\end{array}$ & $\begin{array}{l}2.18 \\
2.126\end{array}$ & $\begin{array}{l}25 \\
30\end{array}$ & $\begin{array}{l}2.327 \\
2.223\end{array}$ & $\begin{array}{r}5 \\
20\end{array}$ \\
\hline $\begin{array}{l}13,10 \\
02,16\end{array}$ & $\begin{array}{c}2.138 \\
\ldots \ldots \ldots\end{array}$ & $\begin{array}{r}10 \\
5\end{array}$ & 2.058 & 20 & $\begin{array}{l}2.144 \\
2.140\end{array}$ & $\begin{array}{r}8 \\
10\end{array}$ \\
\hline $\begin{array}{l}048 \\
324\end{array}$ & 2.095 & $\begin{array}{l}10 \\
10\end{array}$ & 2.021 & 15 & 2.099 & 15 \\
\hline 410 & 2.063 & 10 & & & & \\
\hline $\begin{array}{r}232 \\
40,10\end{array}$ & $\begin{array}{l}2.018 \\
\ldots \ldots \ldots \ldots\end{array}$ & $\begin{array}{r}3 \\
\ldots \ldots\end{array}$ & & & & \\
\hline $\begin{array}{r}21,16 \\
238 \\
416\end{array}$ & $\begin{array}{l}1.989 \\
1.953 \\
1.943\end{array}$ & $\begin{array}{l}15 \\
40 \\
15\end{array}$ & $\begin{array}{l}1.914 \\
1.888 \\
1.870\end{array}$ & $\begin{array}{l}10 \\
15 \\
15\end{array}$ & $\begin{array}{l}1.995 \\
1.958 \\
1.944\end{array}$ & $\begin{array}{l}10 \\
40 \\
10\end{array}$ \\
\hline $01,20,3114$ & $\begin{array}{l}1.884 \\
1.865\end{array}$ & $\begin{array}{l}10 \\
10\end{array}$ & $\begin{array}{l}1.797 \\
\ldots \ldots \ldots\end{array}$ & 20 & $\begin{array}{l}1.871 \\
\ldots \ldots \ldots\end{array}$ & $\begin{array}{c}3 \\
\ldots \ldots\end{array}$ \\
\hline $\begin{array}{l}502 \\
054\end{array}$ & $\begin{array}{l}1.857 \\
1.831 \\
1.812\end{array}$ & $\begin{array}{r}10 \\
10 \\
3 .\end{array}$ & 1.771 & 10 & $\begin{array}{l}1.860 \\
1.836\end{array}$ & $\begin{array}{l}10 \\
10\end{array}$ \\
\hline $\begin{array}{r}330 \\
20,20 \\
30,18,13,16\end{array}$ & $\begin{array}{l}1.794 \\
1.776 \\
1,761\end{array}$ & $\begin{array}{r}5 \\
20 \\
15\end{array}$ & $\begin{array}{l}1.737 \\
1.668 \\
1.657\end{array}$ & $\begin{array}{l}10 \\
20\end{array}$ & $\begin{array}{l}1.799 \\
1.779\end{array}$ & $\begin{array}{r}5 \\
20\end{array}$ \\
\hline 508 & 1.737 & 3 & & & & \\
\hline
\end{tabular}

Cerite was not found in previous studies of rareearth oxides-silica systems. Divalent ions play an essential role in the formation of cerite. The compositional range of cerites and a part of that of apatites in terms of ionic radii of the divalent ions and the rare-earth ions has been determined and is given in figure 1. It appears likely that the divalent and rareearth ion sites are ordered, and that no appreciable partial replacement of rare-earth sites by divalent ions takes place. Unit-cell dimensions of the cerite change only when the size of either the divalent or the rare-earth ion is changed, but not when the ratio of the amounts of two given cations in the source material is changed. A calcium end member of cerite phase does not exist under the present conditions, although the chemical analyses of natural cerite usually show several percent of calcium. The Mn analogs are converted to Mn-apatite at temperatures above $650{ }^{\circ} \mathrm{C}$ under $2 \mathrm{kbar} \mathrm{H}_{2} \mathrm{O}$ pressure. The tentative boundary for cerite apatite conversion at $550{ }^{\circ} \mathrm{C}$ under $2 \mathrm{kbar}$ is drawn in figure 1 . The reverse reaction has not been observed, possibly because the reaction is too slow; but it may be that the equilibrium phase field for apatite is larger than indicated.

All the analogs of cerite were converted into apatite or apatite plus other phases after dehydration in air at temperatures above $900^{\circ} \mathrm{C}$. It was quite unexpected that the smaller rare-earth ions such as Dy or $\mathrm{Ho}_{0}$ also form cerite, because cerites found in nature contain exclusively large size rare-earth ions such as: $\mathrm{La}, \mathrm{Ce}, \mathrm{Pr}, \mathrm{Nd}$, and $\mathrm{Sm}$.

Magnesium replacement in whitlockite was limited at the composition, $\mathrm{Ca}_{7} \mathrm{Mg}_{2} \mathrm{P}_{6} \mathrm{O}_{24}$. Starting material containing more $\mathrm{Mg}$ than corresponds to this end member gave an inferior whitlockite $\mathrm{x}$-ray powder pattern without change in the unit-cell dimensions. With further increase of $\mathrm{Mg}$ in the charge, a second phase $\mathrm{Ca}_{3} \mathrm{Mg}_{3}\left(\mathrm{PO}_{4}\right)_{4}$ appears. The whitlockite solidsolution series is demonstrated in figure 2. Unit-cell dimensions vary as a function of $\mathrm{Mg}$ content.

Only a partial solid-solution series exists between cerite and whitlockite despite their close isomorphism 
ABLE 3. X-ray powder diffraction data for synthetic Mg-whitlockite $\mathrm{Ca}_{7} \mathrm{Mg}_{2} \mathrm{P}_{6} \mathrm{O}_{24}$. $\left(\mathrm{Cu} \mathrm{K} \alpha\right.$, Ni filter; $1150{ }^{\circ} \mathrm{C}$ in air $)$

Space group R3c, Hexagonal.

\begin{tabular}{|c|c|c|c|}
\hline \multicolumn{2}{|c|}{$a=10.31 \AA$} & \multicolumn{2}{|c|}{$c=37.23 \AA$} \\
\hline $\begin{array}{l}h k l \\
012 \\
104 \\
110 \\
202 \\
018\end{array}$ & $\begin{array}{l}d \text { obs. } \AA \\
8.05 \\
6.43 \\
5.15 \\
4.333 \\
4.130\end{array}$ & $\begin{array}{l}I / I_{0} \\
20 \\
33 \\
50 \\
20 \\
20\end{array}$ & $\begin{array}{l}d \text { calc. } \AA \\
8.04 \\
6.44 \\
5.15 \\
4.337 \\
4.126\end{array}$ \\
\hline $\begin{array}{r}024 \\
10,10 \\
211 \\
122 \\
208\end{array}$ & $\begin{array}{l}4.019 \\
3.437 \\
3.358 \\
3.316 \\
3.227\end{array}$ & $\begin{array}{l}20 \\
45 \\
15 \\
20 \\
20\end{array}$ & $\begin{array}{l}4.023 \\
3.437 \\
3.357 \\
3.304 \\
3.219\end{array}$ \\
\hline $\begin{array}{r}214 \\
300 \\
02,10 \\
128 \\
306\end{array}$ & $\begin{array}{l}3.160 \\
2.972 \\
2.857 \\
2.730 \\
2.685\end{array}$ & $\begin{array}{r}75 \\
30 \\
100 \\
30 \\
20\end{array}$ & $\begin{array}{l}3.159 \\
2.973 \\
2.859 \\
2.731 \\
2.683\end{array}$ \\
\hline $\begin{array}{r}11,12 \\
220 \\
01,14 \\
223 \\
21,10\end{array}$ & $\begin{array}{l}2.660 \\
2.577 \\
2.525 \\
2.525 \\
2.503\end{array}$ & $\begin{array}{l}15 \\
70 \\
15 \\
15 \\
25\end{array}$ & $\begin{array}{l}2.659 \\
2.575 \\
2.551 \\
2.521 \\
2.500\end{array}$ \\
\hline $\begin{array}{r}226 \\
12,11 \\
315 \\
10,16 \\
11,15\end{array}$ & $\begin{array}{l}2.384 \\
\\
2.347 \\
2.250 \\
2.239\end{array}$ & $\begin{array}{l}10 \\
15 \\
10 \\
10\end{array}$ & $\begin{array}{l}2.378 \\
2.384 \\
2.349 \\
2.252 \\
2.240\end{array}$ \\
\hline $\begin{array}{r}404 \\
30,12 \\
21,14 \\
321 \\
232\end{array}$ & $\begin{array}{l}2.169 \\
2.148 \\
2.093 \\
2.039\end{array}$ & $\begin{array}{l}20 \\
20 \\
10 \\
10\end{array}$ & $\begin{array}{l}2.169 \\
2.147 \\
2.089 \\
2.043 \\
2.034\end{array}$ \\
\hline $\begin{array}{r}324 \\
048 \\
22,12 \\
11,18 \\
40,10\end{array}$ & $\begin{array}{l}2.013 \\
\\
2.003 \\
1.916\end{array}$ & $\begin{array}{l}15 \\
10 \\
30\end{array}$ & $\begin{array}{l}1.999 \\
2.012 \\
1.982 \\
1.920 \\
1.913\end{array}$ \\
\hline $\begin{array}{r}238 \\
416 \\
01,20 ; 31,14 \\
32,10 \\
502\end{array}$ & $\begin{array}{l}1.879 \\
1.839 \\
1.824 \\
1.795 \\
1.762\end{array}$ & $\begin{array}{l}20 \\
20 \\
20 \\
10 \\
10\end{array}$ & $\begin{array}{l}1.873 \\
1.857 \\
1.823 \\
1.794 \\
1.776\end{array}$ \\
\hline $\begin{array}{r}054 \\
20,20 \\
30,18\end{array}$ & $\begin{array}{l}1.753 \\
1.719 \\
1.700\end{array}$ & $\begin{array}{l}10 \\
30 \\
15\end{array}$ & $\begin{array}{l}1.752 \\
1.719 \\
1.724\end{array}$ \\
\hline
\end{tabular}

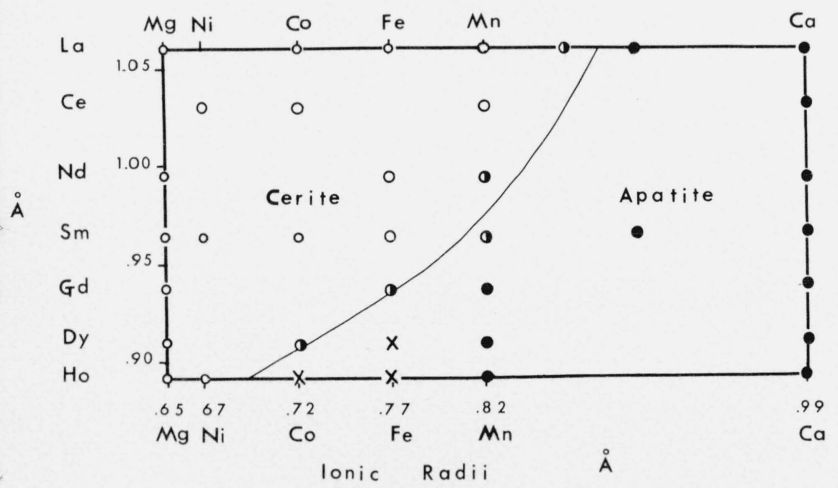

Figure 1. Compositional stability range of cerites.

Abscissa is the ionic radii for divalent cations given by Wells (1962) [9], ordinate is rareearth radii given by Templeton and Dauben (1954) [10].

and close structural relationship. Large fields of stability for phospho-silico-apatites and monazites are present between the two compounds under the conditions used in the present experiments. Limited solid solution may extend from one toward the other. The

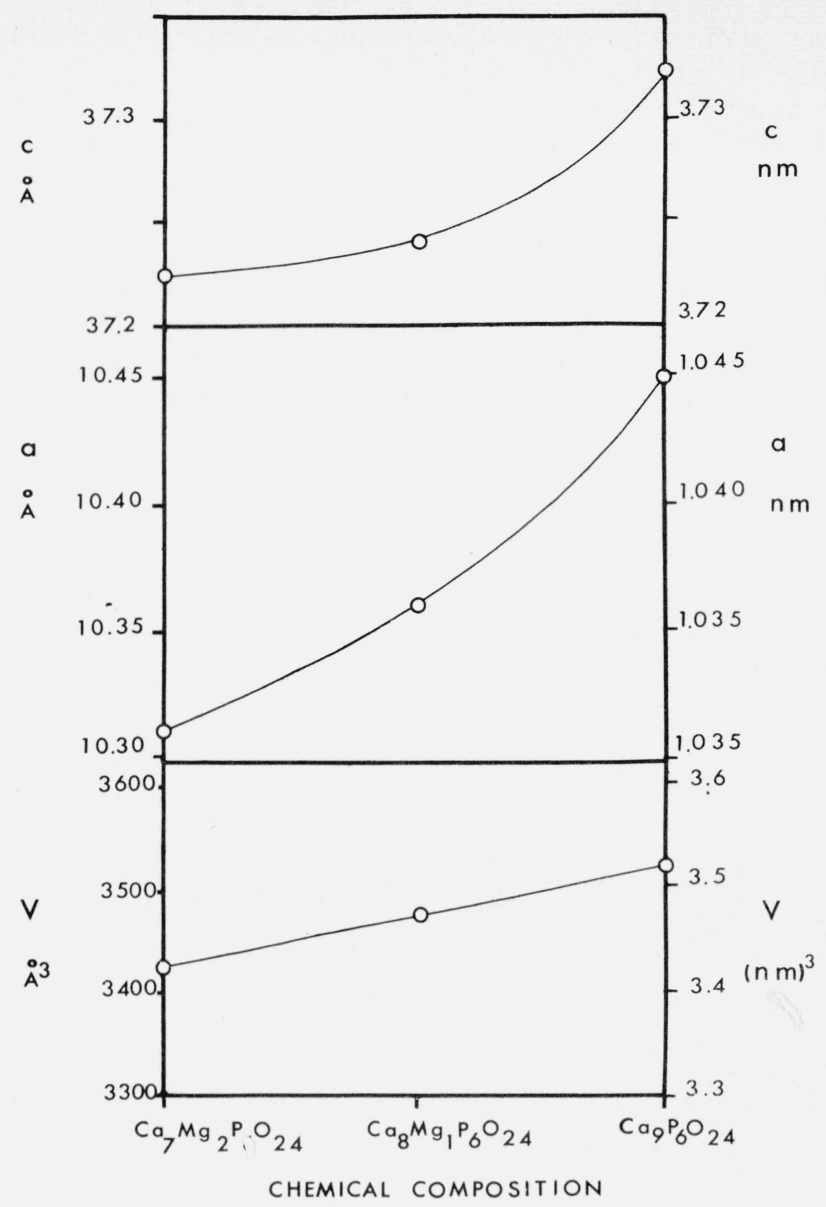

FIGURE 2. Whitlockite and Mg-whitlockite solid-solution series. Open circles $=$ cerite closed circles $=$ apatite, crosses $=$ mixed unidentified phases

probable limits of solid solution may be around $\mathrm{CaMg}_{2} \mathrm{Ln}_{6} \mathrm{Si}_{5} \mathrm{PO}_{23}(\mathrm{OH})_{3}$ for cerite, and $\mathrm{Ca}_{8} \mathrm{LnP}_{5} \mathrm{SiO}_{24}$ for whitlockite, but there is evidence to indicate that the solid-solution limit is a function of the size of rare-earth ion.

Infrared absorption spectroscopic analysis by R. Wilkins at Harvard University, showed abundant hydroxyl ion (up to several percent) in the synthetic Mg-La cerite possibly in two crystallographic sites $\left(3690 \mathrm{~cm}^{-1}\right.$ strong infrared line and $3660 \mathrm{~cm}^{-1}$ medium line). Synthetic $\mathrm{Ca}$ and $\mathrm{Ca}-\mathrm{Mg}$ whitlockite, however were shown to be anhydrous as originally expected.

Europium and terbium activation of Mg-Gd analogs of cerite show typical red and yellow visible emission under a mercury fluorescent lamp, but their luminescent intensities are much lower than those displayed by the silicate apatites [1].

From the results here presented, the formula $\mathrm{M}_{2}^{2+} \mathrm{Ln}_{7} \mathrm{Si}_{6} \mathrm{O}_{23}(\mathrm{OH})_{3}$ seems in best agreement with the chemical analysis, infrared analysis, and synthesis of cerites. This formula is essentially the same as that given by Gay [6] and is isomorphous with $\mathrm{Mg}$ whitlockite except for two additional hydroxyl ions. However, calcium and magnesium ions in cerite do 
not seem to be distributed randomly within rare-earth sites as suggested by Gay.

In the absence to date of a complete $\mathrm{x}$-ray structure determination on cerite, the experimental results could be given an alternative interpretation by the following formulas:

$\mathrm{M}_{3}^{2+} \mathrm{Ln}_{7} \mathrm{Si}_{7} \mathrm{O}_{27} \mathrm{OH} \cdot \mathrm{H}_{2} \mathrm{O}$ or $\mathrm{M}_{2}^{2+} \mathrm{Ln}_{8} \mathrm{Si}_{7} \mathrm{O}_{28} \cdot 3 \mathrm{H}_{2} \mathrm{O}$.

They correspond to that suggested by Keppler [8] for whitlockite. The latter formula was also that given by Glass et al. [7], from their extensive study on natural cerite from Mountain Pass, California.

Support by the Advanced Research Projects Agency is gratefully acknowledged.

\section{References}

[1] Ito, J., Am. Min. 53, July-August, in press (1968).

[2] Hisinger, W. and Berzelius, J., Neues Allg. Jour. Chemie, 2, 397 $418(1804)$

[3] Hisinger, W., and Berzelius, J., Abhandl. Fysik, Kemiocl Mineralogie, 1, 58-84 (1806).

[4] Silberminz, V., Acad. Sci., USSR, C.R. A, 55, Abs. Neue Jahrb. Min., 1, 123 (1930).

[5] Goddard, E. N., and Glass, J. J., Am. Min. 25, 381-404 (1940)

[6] Gay, P., Min. Mag. 31, 455-469 (1957).

[7] Glass, J. J., Evans, H. T., Jr., Carron, M. K., and Hildebrand F. A., Am. Min. 43, 460-475 (1958).

[8] Keppler, U., Naturwissenchaften, 54, 139 (1967).

[9] Wells, A. F., Structural Inorganic Chemistry, 3rd ęd., p. 483 (Clarendon Press, Oxford, 1962).

[10] Templeton, D., and Dauben, C. H., J. Am. Chem. Soc. 76 5237-5239 (1954). 